\section{CONFERENCE} IN CRETE

"I most appreciate the opportunity I had here for communication between these different fields; this was very valuable to me," Mats Hillert of Sweden's Royal Institute of Technology said of the MRS-sponsored International Conference on Phase Transformations in Solids, held in Crete June 27 - July l. As a scientist with a theoretical background in modulated structures and a present interest in the more practical aspects of steel properties and production, he typifies the multidisciplinary scientist MRS technical meetings are intended to serve.

And, to judge from the enthusiastic reports received from the conference in Crete, participants there were well served, indeed. Some 170 scientists and engineers from 26 nations attended. They heard 33 invited and 30 contributed papers, and had access to 112 poster presentations in 12 technical and three poster sessions.

"I am overwhelmed over everything I have seen," said Jim Taylor of Rutgers, the state university of New Jersey. "I have seen a large number of absolutely fascinating geometrical structures in this conference, and it seems to me that this is a wide-open area for a lot of mathematics that have not been created yet, mathematics on minimum surfaces."

Robert Sinclair of Stanford University said, "We were seeing things in slides and posters in this conference that would have seemed inconceivable ten years ago - or maybe five years ago; things such as a field ion micrograph and electron micrograph, computer simulations from the $\mathrm{X}$-ray and neutron diffraction methods and many others. The fine scale on which we are examining solids now is the most impressive point about this conference,

[Continued on Page 5]
Maleme-Chania, Crete, Greece

June 27, 1983

E.P. Velikov, Vice President

Y.A. Ovcchinnikov, Vice President

Academy of Sciences of the USSR

Moscow, USSR

Sirs:

We, the undersigned attendees at the International Conference on Phase Transformations in Solids, formally protest your refusal to permit Professor Armen Khachaturyan and his wife, Svetlana Semanovskaya-Khachaturyan, to participate in this conference.

Both are outstanding scientists in the field. Professor Khachaturyan was invited to be our keynote speaker. Their absence is deeply felt. Your action is a disservice to international science that reflects badly on your Academy.

We are distressed to learn that this action is only the most recent step in a pattern of professional harassment of the Khachaturyan family. We understand that Professor Khachaturyan has been expelled from scientific councils, that his wife has been denied the fundamental right of a scientist to publish her results, and that their son, Karen Khachaturyan, a young physicist of outstanding promise, has been expelled from Moscow University and denied the opportunity to pursue a career in science. All of this happened, we understand, in retribution for the Khachaturyan application for exit visas to join their relatives abroad, despite the fact that their right to do so is guaranteed by international agreements ratified by the Soviet Union.

We are sad to hear that the burden of this persecution has driven Professor Khachaturyan to go on a hunger strike for the duration of the conference, in company with Soviet scientific colleagues who are in a similar position. We extend our support and sympathy to him as physicists and materials scientists from many countries.

The Soviet Union has often expressed its desire to participate in the activities of international science. You must certainly realize that such participation brings obligations as well as privileges, and that the most fundamental of these obligations is to promote, rather than hinder, the international exchange of scientists and scientific information.

You must certainly understand that this action has caused serious discussions among many of us regarding the desirability of future invitations to those Soviet scientists who are permitted to travel. We urge you to use your good offices to end these restrictions on scientific discussion, and to stop this senseless persecution of outstanding scientists.

Many of us have known Professor Khachaturyan well for many years. We know that he has not engaged in research of a classified or defense nature, and we therefore cannot understand the reluctance of the Soviet Government to permit the Khachaturyan family to join their relatives abroad. We further urge you to recommend reconsideration of their applications for exit visas.

[There follow the signatures of 103 scientists.] 


\title{
SHORT-COURSE INSTRUCTORS
}

\author{
The scientists who will teach short courses \\ in liquid phase epitaxy, surface analysis and ion implantation
}

A distinguished group of scientists, including a Von Hippel Award winner, have consented to teach a total of three short course at this November's Annual Meeting in Boston.

\section{Surface Analysis}

The short course on surface analysis techniques, which will present the conceptual and practical aspects of modern surface and thin film analysis, will be taught by Len Feldman of Bell Labs and Jim Mayer of Cornell.

LEONARD C. FELDMAN received his Ph.D. from Rutgers in 1967. Since then he has been a Member of the Technical Staff of Bell Laboratories, except forf a one-year leave of absence at Aarhus University in Demark. Throughout his scientific career he has been active in education: he is an instructor in Bell Labs' "In-hours" education program, and at Drew University and Cornell. His publications include a book, Materials
Analysis by Ion Channeling, with J.W. Mayer and S.T. Picraux, and numerous articles on materials science-related subjects. His most recent research interests include the structure and analysis of surfaces and interfaces and their interrelationship. $\mathrm{He}$ is a Fellow of the American Physical Society and a recipient of Bell Labs' Distinguished Technical Staff Award. Moreover, it was Len who, as Chairman of the Society's Education Committee, organized the expansion of the shortcourse element of the Annual Meeting, which began as an experiment with a single course last year and promises to grow further in coming years.

JAMES W. MAYER is Bard Professor of Materials Science at Cornell University. In 1981 he was honored with the MRS's most prestigious prize, the Von Hippel

\section{[Continued on Page 6]}

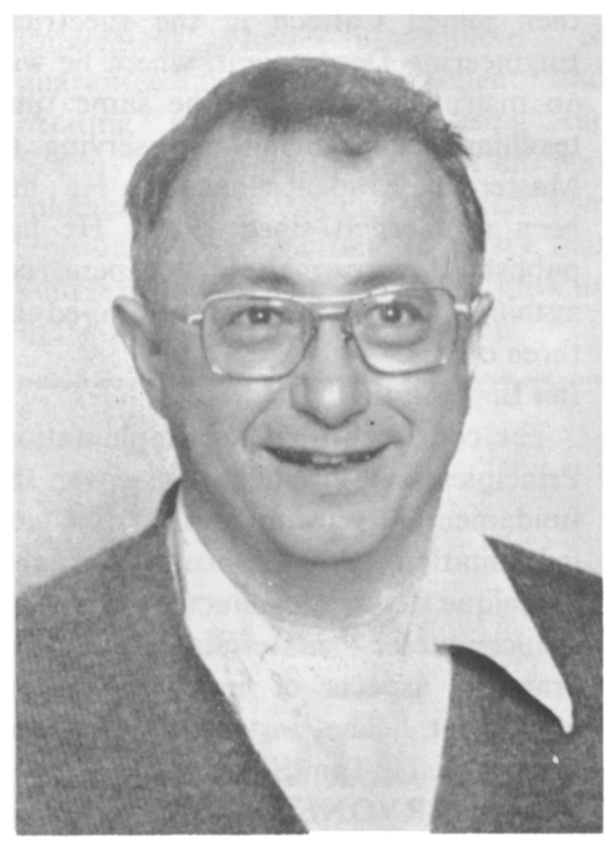

JIM MAYER

\section{[Continued from Page 4]}

CRETE still remain." and I think that will lead to a deeper understanding of the problems which

Conference organizer Tom Tsakalakos of Rutgers said, "This uncommon gathering of scientists assured a uniform representation of all aspects of phase transformations and provides the basis for future collaboration between groups that traditionally have not established contacts before." Tsakalakos also pointed out that the location attracted a broadly international group.

Soviet Couldn't Attend

Sadly, the meeting's keynote speaker, Armen Khachaturyan, and his wife were refused permission by their government to attend. In a dramatic letter smuggled out of the Soviet Union and published in the last issue of the Bulletin, the scientist revealed that he is a refusenik, who has been denied permission to emigrate and subjected to various forms of harassment for seeking to do so. He told conference organizers he would participate in a hunger strike during the session's length. This led a score of those attending the conference to observe a limited fast in sympathy with Khachaturyan's plight. Also, a substantial majority of those who attended the meeting signed a letter of protest that was dispatched to the Soviet Academy of Science. [That letter is reprinted in these pages.] 